\title{
Stomatal and Cuticular Transpiration of Greenhouse Tomato Plants in Response to High Solution Electrical Conductivity and Low Soil Water Content
}

\author{
Hui-lian $\mathrm{Xu}^{1}$, Laurent Gauthier ${ }^{2}$, and André Gosselin ${ }^{3}$ \\ Horticulture Research Center, Faculty of Agriculture and Food, Laval University, PQ, G1K 7P4, Canada
}

Additional index words. cuticular wax, Lypersicon esculentum, electrical conductivity, water stress

\begin{abstract}
Capello' tomato plants (Lycopersicon esculentum Mill.) were grown in a greenhouse in peat-based substrate (70\% sphagnum peat and 309'. perlite, by volume) and supplied with nutrient solutions of high $\left(4.5 \mathrm{mS} \cdot \mathrm{cm}^{-1}\right)$ or low $\left(2.3 \mathrm{mS} \cdot \mathrm{cm}^{-1}\right)$ electrical conductivity $(\mathrm{EC})$ under high $(95 \% \pm 5 \%)$ or low $(55 \% \pm 8 \%$ of capillary capacity) soil water conditions. Three weeks after treatments started, stomatal transpiration $\left(T^{\mathrm{st}}\right)$ and cuticular transpiration $\left(\mathrm{TR}^{\mathrm{cu}}\right)$ rates were measured by three methods: 1 ) analyzing $T R^{\mathrm{st}}$ and $T R^{\mathrm{cu}}$ from a water retention curve obtained by drying excised leaves in air under a photosynthetic photon flux (PPF) of $\left.400 \mu \mathrm{mol} \cdot \mathrm{m}^{-2} \cdot \mathrm{s}^{-1}, 2\right)$ analyzing $\mathrm{TR}^{\mathrm{st}}$ and $\mathrm{TR}^{\mathrm{cu}}$ from a transpiration decline curve obtained by measuring transpiration rates after cutting the leaf from the stem of the dehydrated plant in the gas-exchange system, and 3) measuring transpiration rates under light and in dark respectively using the gas-exchange method. TR ${ }^{\text {st }}$ and $T R^{\text {cu }}$ were decreased by high EC and/or low soil water content. For method 1, the transpiration decline curve shows two distinct phases: the initial steep slope that indicates $T^{\mathrm{st}}$ and the gently sloped section that indicates $\mathrm{TR}^{\mathrm{cu}}$. Both slopes were lower for high EC and/or water-stressed plants compared to the control (low EC and high soil water content). The tangent lines of these two phases of the curve intersect at one point $(t, w)$. The value oft that indicates the time for stomatal closure was longer and the value of $\mathrm{w}$ that indicates the critical tissue water level for stomatal closure was lower for high EC and/or water-stressed plants. In method 2, the initial rate of total transpiration was higher in high EC and/or water-stressed plants. Leaf wax content increased, especially under high EC stress. This suggests that increased deposition of wax prevents water loss from the cuticle. A delay in complete stomatal closure, complete closure at lower RWC, and reduced $T^{\mathrm{cu}}$ or an increase in wax deposit were adaptations to water and salinity stresses in tomato plants under our controlled environmental conditions.
\end{abstract}

The effects of electrical conductivity (EC) of the nutrient solution and substrate water content (SWC) on photosynthesis and water relations of tomato plants grown in peat-based substrates (70\% sphagnum peat and 30\% perlite, by volume) in a greenhouse were examined in a previous study (Xu et al., 1994). Photosynthesis was significantly decreased by high EC and/or low SWC. However, water use efficiency $\left(\mathrm{CO}_{2}\right.$ fixed relative to water transpired) was increased, indicating that the balance between photosynthesis and transpiration was altered. Reduced transpiration is an important physiological indicator of stress (Chaves, 1991; Chaves and Rodrigues, 1987; Osmond et al., 1987). Leaf transpiration includes stomatal transpiration $\left(\mathrm{TR}^{\mathrm{st}}\right)$ and cuticular transpiration $\left(\mathrm{TR}^{\mathrm{cu}}\right)$. Under water deficit conditions, $\mathrm{TR}^{\mathrm{st}}$ is controlled by stomatal conductance, which is mainly determined by tissue water status at a given vapor pressure difference between the leaf surface and air. TR ${ }^{\mathrm{cu}}$ is affected by the characteristics of the leaf surface, such as the thickness of the wax layer and morphological structure (Richards et al., 1987). Cuticular waxes are embedded in the cutin matrix and cover the outer surface of the leaf cuticle. Cuticular waxes, together with stomatal resistance, constitute the water vapor diffusion barrier across the leaf-air interface (Schönherr, 1982). When water deficit is severe enough to induce stomatal closure, the transpirational water loss is determined by the cuticu-

Received for publication 26 July 1994. Accepted for publication 10 Oct. 1994. Laval Univ. Horticulture Research Center publication no. 135. We thank Natural Science and Engineering Research Council of Canada, Agriculture Canada, Agriculture Quebec, and Sylvania Ltd. for the financial support as well as Serge Gagnon, Josée Charbonneau, Linda Gaudreau, and Rachel Daigle for their generous help and technical assistance. The cost of publishing this paper was defrayed in part by the payment of page charges. Under postal regulations, this paper therefore must be hereby marked advertisement solely to indicate this fact.

'Postdoctoral fellow.

${ }^{2}$ Professor, Dept. of Agricultural Engineering.

${ }^{3}$ Professor, Dept. of Plant Science. lar conductance. The increase in waxes deposited in and on the leaf cuticle is one of the most obvious forms of stress acclimation (Jordan et al., 1983). The amount of cuticular waxes is increased by conditions such as high light intensity, high temperature, low humidity, and soil water deficit (Baker, 1974, 1982; Bengtson et al., 1978; Haas, 1977; Svenningsson and Lijenberg, 1986; Whitecross and Armstrong, 1972). However, the effect of high EC on cuticular waxes and $\mathrm{TR}^{\mathrm{cu}}$, especially in tomato plants, is not documented. This research was designed to examine the effects of high $\mathrm{EC}$ and soil water deficit on $\mathrm{TR}^{\mathrm{st}}$ and $\mathrm{TR}^{\mathrm{cu}}$ using different methods. The effects of high EC and water deficit on leaf surface wax was also examined and related to $\mathrm{TR}^{\mathrm{cu}}$.

\section{Materials and Methods}

Plant material and treatment. 'Capello' tomato seeds were sown in small rockwool cubes $(3.8 \times 3.6 \times 4.0 \mathrm{~cm}$, Pargro Co., Caledonia, Ontario, Canada) in seedling packs. The seedlings were transplanted to rockwool blocks $(10 \times 10 \times 10 \mathrm{~cm}$, Pargro $)$ when they were established. Five weeks after sowing, the plants were transplanted into 6-liter plastic pots filled with a peat-based substrate (70\% sphagnum peat and 30\% perlite, by volume) (Premier Peat Moss, Rivière-du-loup, Quebec, Canada). The plants were grown in a greenhouse constructed of double-layered polyethylene. The temperature in the greenhouse was maintained at $21 \pm 1 \mathrm{C} /$ $18 \pm 1 \mathrm{C}$ (day/night). The relative humidity $(\mathrm{RH})$ fluctuated with time of day between $50 \%$ and $80 \%$. When the fifth leaf from the soil surface was fully expanded, the plants were divided into four plots and supplied with nutrient solutions with high $\left(4.5 \mathrm{mS} \cdot \mathrm{cm}^{-1}\right)$ and low $\left(2.3 \mathrm{mS} \cdot \mathrm{cm}^{-1}\right)$ EC combined with high $(95 \% \pm 5 \%)$ and low $(55 \% \pm 8 \%$ of the capillary capacity) SWC. EC was raised by increasing the concentration of the nutrient solution, based on the fact that, in a nutrient solution with a EC higher than $2.3 \mathrm{mS} \cdot \mathrm{cm}^{-1}$, 
concentration of nutrients is no more the limiting factor and EC becomes the dominate factor affecting tomato plant growth and physiology. Compositions of the nutrient solutions with a EC of 2.3 and $4.5 \mathrm{mS} \cdot \mathrm{cm}^{-1}$ are presented in Table 1 . The experimental design was the randomized complete block as a $2 \times 2$ factorial with two levels of EC and two levels of SWC. Treatments included with five replicate plots and six plants per plot. The plant density was

Table 1. Composition of nutrient solutions with low electrical conductivity (EC) $\left(2.3 \mathrm{mS} \cdot \mathrm{cm}^{-1}\right)$ and high $\mathrm{EC}\left(4.5 \mathrm{mS} \cdot \mathrm{cm}^{-1}\right)$ used in this experiment.

\begin{tabular}{lcc}
\hline \hline & \multicolumn{2}{c}{ Nutrient concn $\left(\mathrm{mmol}^{-1}\right.$ liter $\left.^{-1}\right)$} \\
\cline { 2 - 3 } Element & Low EC & High EC \\
\hline Nitrogen & 10.1 & 19.7 \\
Phosphorus & 1.7 & 3.3 \\
Potassium & 7.2 & 13.8 \\
Calcium & 3.5 & 6.8 \\
Magnesium & 1.8 & 3.5 \\
Iron & 0.0726 & 0.1421 \\
Manganese & 0.0180 & 0.0354 \\
Zinc & 0.0076 & 0.0149 \\
Copper & 0.0016 & 0.0030 \\
Boron & 0.0282 & 0.0510 \\
Molibdenum & 0.0006 & 0.0011 \\
\hline
\end{tabular}

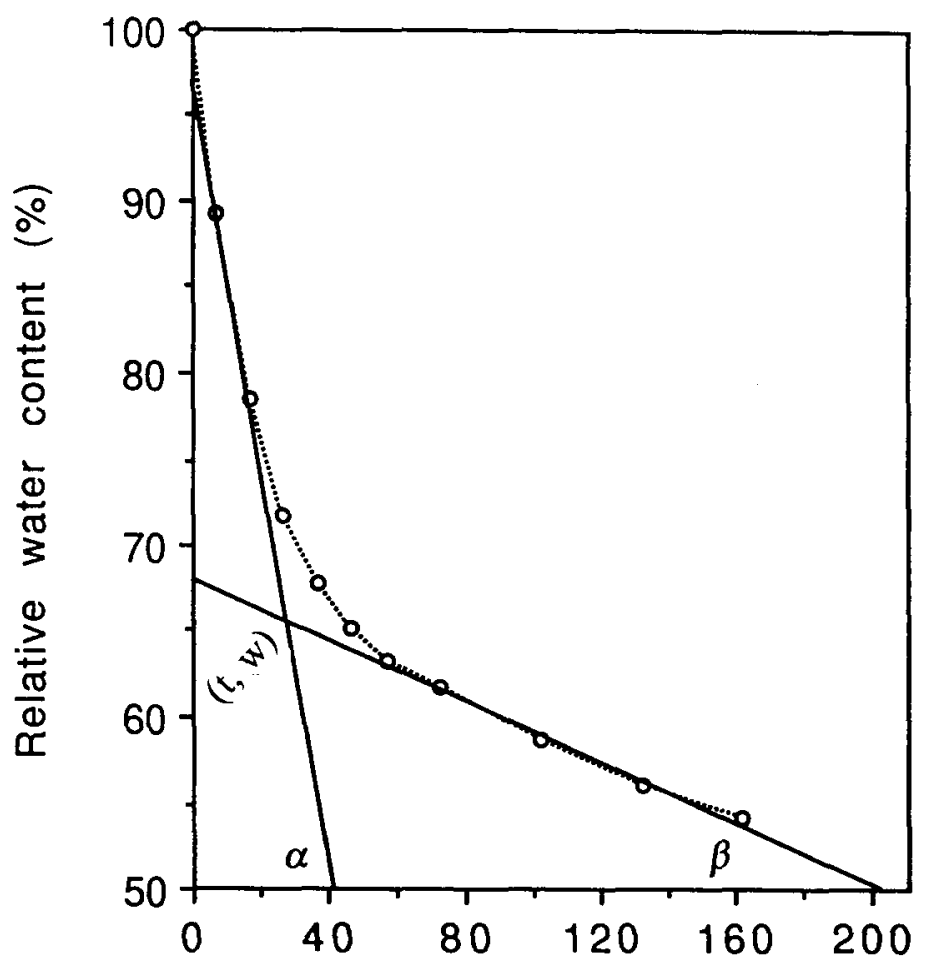

Time (min)

Fig. 1. An example of a water retention curve (dotted fine) of excised tomato leaves of control plants. This is an example of one case of four measurements. The curve (dotted line) was obtained by connectingtle points of data from a single meawrement. The point $(\mathrm{t}, \mathrm{w})$ is the mean stomatal closure point (MSC). The value of $\mathrm{t}$ shows the period during which stomata remained open or partially open after the water supply was stopped. The value of w shows the tissue relative water content at which stomata became closed. Stomatal transpiration $\left(\mathrm{TR}^{\mathrm{s}}\right)$ and cuticular transpiration $\left(\mathrm{TR}^{\mathrm{cu}}\right)$ rates are calculated as follows: $\mathrm{TR}^{\mathrm{st}}+\mathrm{TR}^{\mathrm{cu}}=\tan a ; \mathrm{TR}^{\mathrm{cu}}=\tan \beta$. three plants $/ \mathrm{m}^{2}$. Plants were watered twice a day and the soil water level was controlled by weighing the pots. For example of low $\mathrm{SWC}$, the pots were watered up to $63 \%$ when the SWC reached $47 \%$. No leaching occurred and the salts were allowed to accumulate in the substrate during the treatment (Xu et al., 1994).

\section{Transpiration measurement}

Three weeks after the beginning of treatments, transpiration rates were examined by one of the following methods.

1) Water retention curve with excised leaves. Six leaf sections each with three top leaflets were cut as one sample from the 10th, 11 th, and 12th leaves. The leaves were cut under water and the cut ends were placed in water with the leaf blades in air at saturated water vapor pressure. The bucket was covered and kept in a cool room with an air temperature of $15 \mathrm{C}$. The leaves were dehydrated to fully turgid state for about $12 \mathrm{~h}$. The leaf samples were then placed under light in air saturated with water vapor in a closed acrylic container for $30 \mathrm{~min}$ to allow the stomata to open. The petiole was cut underwater and the leaf laminas were placed on a net fixed on a light paper box (similar to a tissue paper box) under $400 \mu \mathrm{mol} \cdot \mathrm{m}^{-2} \cdot \mathrm{s}^{-1}$ of PPF at $60 \% \mathrm{RH}$. The fresh weight of the leaf sample was weighed at 2-15 min intervals using an electronic balance. Changes in fresh weight were recorded and water loss was determined on a relative basis (Quisenberry et al., 1982). Variables characterizing stomatal and cuticular transpiration and water retention ability were obtained by analyzing the water retention

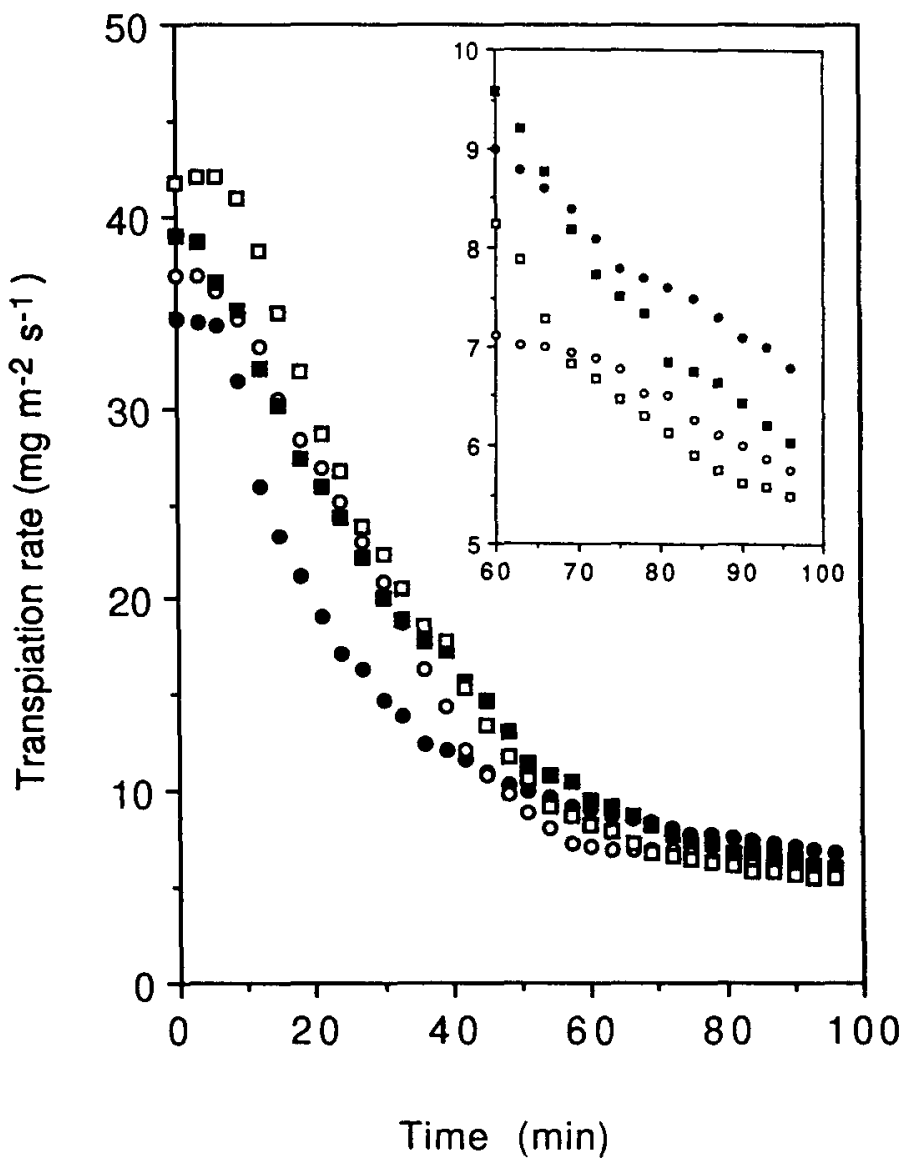

Fig. 2. An example of typical transpiration decline curves measured with the gasexchange method for greenhouse tomato plants grown under high soil water content and low electrical conductivity (EC) [control, 0 ], low soil water content and low EC ( $\bigcirc$ ); high soil water content and high EC $(\boldsymbol{\square})$; and low soil water content and high EC ( $\square$ ) conditions. The mean values of the variables obtained from the four measurements and the statistical significance are presented in Table 3. 
curve. as shown in Fig. 1. This curve exhibits two phases (Quisenberry et al., 1982), the initial deep part and the gentlysloped part. Tangent lines of these two phases each cross with the abscissa, making angles ( $\alpha$ and $\beta$ respectively. The slope of the initial phase, shown by $\tan \alpha$, is defined as the water loss rate by $\mathrm{TR}^{\mathrm{st}}$ and $\mathrm{TR}^{\mathrm{cu}}$. The slope of he gently-sloped part, shown by $\tan \beta$, is defined as the water loss rate by $\mathrm{TR}^{\mathrm{CU}}$. The two tangent lines intersect at one point $(\mathrm{t}, \mathrm{w})$, and this is defined as mean stomatal closure (MSC) point. The value of $t$ shows the time required for the stomata to close completely. The value of $\mathrm{w}$ shows the tissue relative water content (RWC) at which the stomata close. The RWC after 160 min transpiration $\left(\mathrm{RWC}^{160}\right.$ ) shows the integrated ability of tissue water retention of the leaves.

2) Transpiration decline curve with gas-exchange method. Plants in all treatments were irrigated until they were fully turgid and then the accumulated salts were washed out of the substrate by additional irrigation. The top leaflet of the youngest fully expanded leaf was placed in the assimilation chamber and the transpiration rate was measured with the leaf attached to the plant under $600 \mu \mathrm{mol} \cdot \mathrm{m}^{-2} \cdot \mathrm{s}^{-1} \mathrm{PPF}$ using an infrared water vapor analyzer (ADC-225-MK3; Analytical Development Co., Hoddesdon, England) in an open gas-exchange system (Yue et al., 1992). The leaf was then cut from the plants and the cut end was covered with lanolin cream to prevent water loss. The transpiration rate declined as time elapsed. A transpiration decline curve as shown in Fig. 2 was obtained for each sample leaf. Variables characterizing transpiration decline rates were obtained by analyzing the transpiration decline curve in a similar way as that shown in Fig. 1. However, the slopes of the two phases show the declining rate of the transpiration instead of transpiration rate per se. The tangent lines of these two phases intersect at a point (t, TR). The value of $t$ here is defined as the time at which the stomata close. The value of TR is defined as the transpiration rate at which the stomata close. The initial transpiration rate before the leaf is cut is defined as the maximum transpiration rate showing the combined transpiration ability through stomata and cuticle. The transpiration rate after 95 min of declining is defined as the minimum transpiration rate which shows cuticular transpiration ability at that time.

3) Stomatal and cuticular transpiration rates in situ. Transpiration was measured with an infrared $\mathrm{H}_{2} \mathrm{O}$ analyzer (ADC-225MK3; Analytical Development Co.) in an open gas-exchange system (Yue et al., 1992) with the leaf attached to the plant under $1000 \mu \mathrm{mol} \cdot \mathrm{m}^{-2} \cdot \mathrm{s}^{-1} \mathrm{PPF}$ and in dark, respectively. The transpiration rate in dark was defined as $\mathrm{TR}^{\mathrm{cu}}$. $\mathrm{TR}^{\mathrm{st}}$ rate was defined as the difference between the transpiration rates in light and dark.

Wax content measurement. The content of wax on the leaf surface was measured as described by Ebercon et al. (1977). One sample consisted of eight leaf discs with total area of $80 \mathrm{~cm}^{2}$. Each sample was immersed in $50 \mathrm{ml}$ chloroform for $15 \mathrm{sec}$. The extract was filtered and evaporated in a hot water bath. The residue with the beaker was dried in an oven at $65 \mathrm{C}$ over night and weighed using an electronic balance.

Statistical analysis. Variables were obtained from each single measurement. An analysis of variance was carried out on the data of obtained variables using SAS in the randomized completeblock manner as a $2 \times 2$ factorial with two levels of EC and two levels of SWC. Wailer-Duncan multiple comparison tests were taken on the variables in cases of a significant $F$.

\section{Results and Discussion}

\section{Water retention curve with excised leaves}

Effect of low soil water content. Figure 3 shows typical water retention curves for the four measurements. Each curve shows two distinct phases: the initial steep part, the slope of which $(\tan \alpha$, as in Fig. 1) shows the water loss rate by $\mathrm{TR}^{\mathrm{st}}$ plus $\mathrm{TR}^{\mathrm{cu}}$ and the gentlysloped part, the slope of which ( $\tan \beta$, as in Fig. 1) shows the water loss rate by $\mathrm{TR}^{\mathrm{Cu}}$. The tangent lines of these two parts intersect at one point $(\mathrm{t}, \mathrm{w})$. The value oft shows the time required for the stomata to close. The value of $\mathrm{w}$ shows the tissue RWC at which the stomata close. The shape of the water retention curve with excised leaves of water-stressed plants is different from that for control plants (Fig. 3). TR ${ }^{\text {st }}$ and $\mathrm{TR}^{\mathrm{cu}}$ were decreased by low S WC (Table 2). The time for stomatal closure $\left(\mathrm{t}^{\mathrm{sc}}\right)$ was longer in waterstressed plants than in nonstressed plants. Relative water content at which stomata closed $\left(\mathrm{RWC}^{\mathrm{sc}}\right)$ was lower in water-stressed plants, suggesting some acclimation to low water status in waterstressed plants. RWC after 160 min of transpiration $\left(\mathrm{RWC}^{160}\right)$ was higher in water-stressed plants. This suggests that the leaves of water-stressed plants showed high water retention ability when the water supply was halted.

Effect of high EC. $\mathrm{TR}^{\mathrm{st}}$ and $\mathrm{TR}^{\mathrm{cu}}$ were decreased by high $\mathrm{EC}$ (Fig. 3, Table 2). The value of $\mathrm{t}^{\mathrm{sc}}$ was also larger in high EC treated plants, indicating that stomata of high EC treated plants remained open for a longer period than those of control plants. $\mathrm{RWC}^{\mathrm{SC}}$ was lower in high EC treated plants, suggesting acclimation in high EC

Table 2. Effect of electrical conductivity (EC) and soil water content on variables obtained from water retention curve of excised tomato leaves.

\begin{tabular}{|c|c|c|c|c|c|}
\hline \multirow[b]{2}{*}{ Treatment } & \multicolumn{5}{|c|}{ Variable } \\
\hline & $\begin{array}{c}\mathrm{TR}^{\mathrm{st}} \\
(\% / \mathrm{min})\end{array}$ & $\begin{array}{c}\mathrm{TR}^{\mathrm{cu}} \\
(\% / \mathrm{min})\end{array}$ & $\begin{array}{c}\mathrm{t}^{\mathrm{sc}} \\
(\mathrm{min})\end{array}$ & $\begin{array}{c}\mathrm{RWC}^{\mathrm{sc}} \\
(\%)\end{array}$ & $\begin{array}{c}\mathrm{RWC}^{160} \\
(\%)\end{array}$ \\
\hline$\overline{\mathrm{HW} / \mathrm{LEC}}$ & $0.861 \mathrm{a}$ & $0.063 \mathrm{a}$ & $35 \mathrm{c}$ & $67.2 \mathrm{a}$ & $\overline{54.2 \mathrm{c}}$ \\
\hline LW/LEC & $0.736 c$ & $0.052 \mathrm{~b}$ & $38 \mathrm{~b}$ & $64.3 \mathrm{~b}$ & $58.1 \mathrm{~b}$ \\
\hline HW/HEC & $0.814 \mathrm{~b}$ & $0.049 \mathrm{c}$ & $37 \mathrm{~b}$ & $65.4 \mathrm{~b}$ & $58.4 \mathrm{~b}$ \\
\hline LW/HEC & $0.701 \mathrm{~d}$ & $0.033 \mathrm{~d}$ & $40 a$ & $61.9 \mathrm{c}$ & $60.2 \mathrm{a}$ \\
\hline $\mathrm{EC}$ & $*$ & $* *$ & $*$ & $* *$ & $* *$ \\
\hline Water & $* *$ & $* *$ & $* *$ & $* *$ & $* *$ \\
\hline $\mathrm{EC} \times$ water & NS & $*$ & NS & NS & $* *$ \\
\hline
\end{tabular}

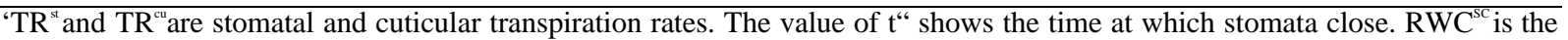
relative water content at which stomata close. $\mathrm{RWC}^{160}$ is the relative water content after $160 \mathrm{~min}$ transpiration. HW/LEC is high soil water content combined with low EC; LW/LEC is low soil water content combined with low EC; HW/HEC is high soil water content combined with high EC; LW/HEC is low soil water content combined with high EC. Percent/rein represents percent of total tissue water lost in $1 \mathrm{~min}$.

"s, ***Nonsignificant or significant at $P \leq 0.05$ or 0.01 , respectively. The values followed by the same letter are not significantly different according to the Wailer-Duncan test $(P \leq 0.05)$. 
treated plants to low leaf water status. $\mathrm{RWC}^{160}$ was higher in high EC treated plants. High EC treated plants showed higher water retention ability than control plants. This high water retention ability was attributed to the deceased $\mathrm{TR}^{\mathrm{st}}$ and $\mathrm{TR}^{\mathrm{cu}}$.

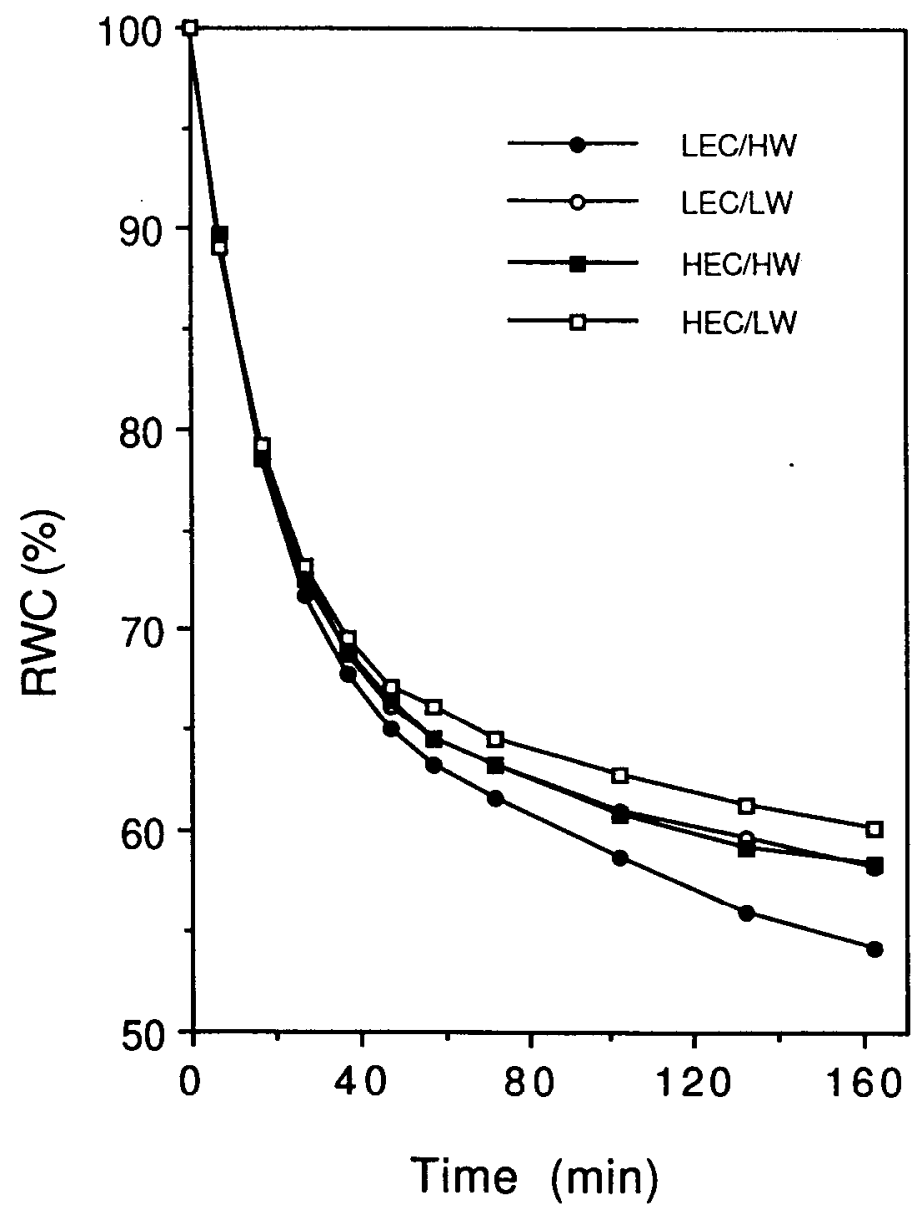

Fig. 3. An example of typical water retention curves of excised leaves of tomato plants grown in a greenhouse under high soil water content and low electrical conductivity (EC) [control (1) LEC/HW], low soil water content and low EC (m, LEC/LW); high soil water content and high EC (n, HEC/HW); and low soil water content and high EC (q, HEC/LW) conditions. These curves represent a typical case of four measurements. The mean values of the variables obtained from the four measurements and the statistical significance are presented in Table 2 .
Combined effect of high EC and low soil water content. High $\mathrm{EC}$ and low substrate water content decreased $\mathrm{TR}^{\mathrm{st}}$ and $\mathrm{TR}^{\mathrm{cu}}$. This is one type of plant adaptation to environmental stress. However, compared with water-stressed plants, high EC treated plants showed higher $\mathrm{TR}^{\mathrm{st}}$ and lower $\mathrm{TR}^{\mathrm{cu}}$. The treatment of high EC combined with low soil water content showed the additive effect of individual low soil water content and high EC. There were significant interactions between $\mathrm{EC}$ and soil water content in $\mathrm{TR}^{\mathrm{cu}}$ and $\mathrm{RWC}^{160}$ (Table 2).

Transpiration decline curve with the gas-exchange method

Effect of low soil water content. Figure 2 shows the transpiration decline curves of one typical case determined by the gasexchange method after the leaf was cut from the stem. The transpiration rate declined as time elapsed. Similar to that in Fig. 1 , the transpiration decline curve shows two distinct phases. The slopes of the two phases show the declining rate of the transpiration. Each curve represents the result of a successive measurements for each sample of each treatment. The maximum transpiration rate before the leaf was cut was higher in previously waterstressed plants than in the constantly well-watered, control plants (Fig. 2, Table 3). This higher transpiration rate might have been due to the turgor recovery caused by dehydration. In another study, turgor potential was higher in previously water-stressed plants than constantly well-watered plants (control) after the stress was released by overwatering the substrate (Xu et al., unpublished data). Higher turgor maintenance accounted for higher transpiration rates. The minimum transpiration rate, which showed the level of $\mathrm{TR}^{\mathrm{cu}}$, was lower in water-stressed plants than in nonstressed plants. The duration of $\mathrm{t}^{\mathrm{sc}}$ was longer in water-stressed plants. The transpiration rate at which stomata closed $\left(\mathrm{TR}^{\mathrm{sC}}\right)$ was lower in water-stressed plants than in nonstressed plants. The stomatal transpiration decline rate $\left(\mathrm{DT}^{\mathrm{st}}\right)$ was higher in water-stressed plants than in control plants (the minus symbol shows that the transpiration was declining, i.e., it was decelerating). This might be attributed to the high initial transpiration rate in the previously water-stressed plants. A small difference in cuticular transpiration decline rates $\left(\mathrm{DT}^{\mathrm{cu}}\right)$ was apparent between the previously waterstressed plants and the control plants.

Effect of high EC. The maximum total transpiration rate $\left(\mathrm{TR}_{\mathrm{MAX}}\right)$ after dehydration was higher in previously high EC treated plants than constantly well-watered, low EC treated control plants (Fig.

Table 3. Effect of electrical conductivity (EC) and soil water content on variables obtained from transpiration decline curve measured with the gas-exchange method

\begin{tabular}{lcccccc}
\hline \hline & \multicolumn{5}{c}{ Variable $^{\mathrm{z}}$} \\
\cline { 2 - 7 } Treatment & $\begin{array}{c}\mathrm{TR}_{\max } \\
\left(\mathrm{mg} \cdot \mathrm{m}^{-2} \cdot \mathrm{s}^{-1}\right)\end{array}$ & $\begin{array}{c}\mathrm{TR}_{\min } \\
\left(\mathrm{mg} \cdot \mathrm{m}^{-2} \cdot \mathrm{s}^{-1}\right)\end{array}$ & $\begin{array}{c}\mathrm{t}^{\mathrm{sc}} \\
(\mathrm{s})\end{array}$ & $\begin{array}{c}\mathrm{TR}^{\mathrm{sc}} \\
\left(\mathrm{mg} \cdot \mathrm{m}^{-2} \cdot \mathrm{s}^{-1}\right)\end{array}$ & $\begin{array}{c}\mathrm{DT}^{\mathrm{st}} \\
\left(\mathrm{mg} \cdot \mathrm{m}^{-2} \cdot \mathrm{s}^{-2}\right)\end{array}$ & $\begin{array}{c}\mathrm{DT}^{\mathrm{cu}} \\
\left(\mathrm{mg}^{\mathrm{cu}} \cdot \mathrm{m}^{-2} \cdot \mathrm{s}^{-2}\right)\end{array}$ \\
\hline HW/LEC & $34.6 \mathrm{~d}$ & $6.4 \mathrm{a}$ & $2520 \mathrm{c}$ & $8.3 \mathrm{c}$ & $-9.2 \mathrm{~b}$ & $-0.88 \mathrm{a}$ \\
LW/LEC & $36.9 \mathrm{c}$ & $5.8 \mathrm{~b}$ & $2820 \mathrm{~b}$ & $7.8 \mathrm{~b}$ & $-10.9 \mathrm{a}$ & $-0.85 \mathrm{~b}$ \\
HW/HEC & $39,1 \mathrm{~b}$ & $6.0 \mathrm{~b}$ & $2880 \mathrm{~b}$ & $7.8 \mathrm{~b}$ & $-9.3 \mathrm{~b}$ & $-0.87 \mathrm{ab}$ \\
LW/HEC & $42.0 \mathrm{a}$ & $5.5 \mathrm{c}$ & $3300 \mathrm{a}$ & $7.2 \mathrm{a}$ & $-11.0 \mathrm{a}$ & $-0.85 \mathrm{~b}$ \\
EC & $* *$ & $* *$ & $* *$ & $* *$ & NS & NS \\
Water & $* *$ & $* *$ & $* *$ & $* *$ & NS & NS \\
EC $\times$ water & NS & NS & NS & NS & NS
\end{tabular}

${ }^{2} \mathrm{TR}_{\max }$ is the maximum transpiration rate at full turgor. $\mathrm{TR}_{\min }$ is the minimum transpiration rate through cuticular surface. The value of $\mathrm{t}^{\mathrm{sc}}$ shows the time at which stomata close. $\mathrm{TR}^{\mathrm{sc}}$ is the transpiration rate at which stomata close. DT is the decline rate of stomata] transpiration and $\mathrm{DT}^{\mathrm{cu}}$ is the decline rate of cuticular transpiration. HW/LEC is high soil water content combined with low EC; LW/LEC is low soil water content combined with low EC; HW/HEC is high soil water content combined with high EC; LW/HEC is low soil water content combined with high EC.

ss, $* * *$ Nonsignificant or significant at $P \leq 0.05$ or 0.01 , respectively. The values followed by the same letter are not significantly different according to Wailer-Duncan test $(P \leq 0.05)$. 
Table 4. In situ stomatal and cuticular transpiration rates and leaf wax content of tomato plants grown in different substrate water and EC conditions.

\begin{tabular}{|c|c|c|c|c|}
\hline \multirow[b]{2}{*}{ Treatment $^{2}$} & \multicolumn{2}{|c|}{ Transpiration in situ $\left(\mathrm{mg} \cdot \mathrm{m}^{-2} \cdot \mathrm{s}^{-1}\right)$} & \multicolumn{2}{|c|}{ Wax content $\left(\mathrm{mg} \cdot \mathrm{m}^{-2}\right)$} \\
\hline & Stomatal & Cuticular & 10th leaf & 15th leaf \\
\hline HW/LEC & $42.4 \mathrm{a}$ & $6.6 \mathrm{a}$ & $30 \mathrm{c}$ & $33 \mathrm{c}$ \\
\hline $\mathrm{LW} / \mathrm{LEC}$ & $28.7 \mathrm{~b}$ & $5.2 \mathrm{~b}$ & $38 \mathrm{~b}$ & $41 \mathrm{~b}$ \\
\hline HW/HEC & $30.1 \mathrm{~b}$ & $4.9 \mathrm{~b}$ & $34 \mathrm{bc}$ & $36 \mathrm{bc}$ \\
\hline LW/HEC & $22.9 \mathrm{c}$ & $4.2 \mathrm{c}$ & $44 \mathrm{a}$ & $47 \mathrm{a}$ \\
\hline EC & $* *$ & $* *$ & $*$ & $* *$ \\
\hline Water & $* *$ & $* *$ & $* *$ & $* *$ \\
\hline EC $\mathrm{x}$ water & $* *$ & $*$ & NS & NS \\
\hline
\end{tabular}

${ }^{2} \mathrm{HW} / \mathrm{LEC}$ is high soil water content combined with low EC; LW/LEC is low soil water content combined with low EC; HW/HEC is high soil water content combined with high EC; LW/HEC is low soil water content combined with high EC.

ns $*$, **Nonsignificant or significant at $P \leq 0.05$ or 0.01 , respectively. The values followed by the same letter are not significantly different according to Wailer-Duncan test $(P \leq 0.05)$.

2, Table 3). In previous studies, the turgor potential was higher in the plants previously treated with high EC than in constantly wellwatered, low EC treated control plants after the accumulated salts were leached from the substrates (unpublished data). The leaves used in this method of the present study were dehydrated to turgid state $(100 \%$ of relative water content). Therefore, higher maximum total transpiration rates in low S WC or high EC treated plants might be due to the turgor recovery caused by dehydration. $\mathrm{TR}_{\min }$ was lower in high EC treated plants than plants of control. This was consistent with $\mathrm{TR}^{\mathrm{cu}}$ in the case mentioned above. The duration of $\mathrm{t}^{\mathrm{sc}}$ was longer and $\mathrm{TR}^{\mathrm{sc}}$ was lower in high EC treated plants. These were consistent with the values of $t^{\text {sc }}$ and $\mathrm{TR}^{\mathrm{SC}}$ in the abovementioned case. $\mathrm{DT}^{\mathrm{st}}$ and $\mathrm{DT}^{\mathrm{cu}}$ were not different between previously high EC treated plants and the control plants. Our results showed that high EC and low soil water affected most variables in an additive way, with the exceptions of $\mathrm{DT}^{\mathrm{st}}$ and $\mathrm{DT}^{\mathrm{cu}}$. Even with similar or slightly larger stomatal transpiration decline rates, tomato plants previously treated with high EC and/or low SWC maintained $\mathrm{TR}^{\text {st }}$ for longer periods. These results were due to the higher initial maximum total transpiration in plants previously treated with high EC and/or low S WC. This phenomenon might be explained by turgor recovery and osmotic adjustment.

Stomatal and cuticular transpirations in situ. $\mathrm{TR}^{\mathrm{st}}$ and $\mathrm{TR}^{\mathrm{cu}}$ measured by the gas-exchange method were lower in plants of high EC, low SWC, and high EC combined with low SWC treatments than low EC-high S WC Plants (Table 3). A comparison between the effects of high EC and low SWC showed that high EC treated plants had a higher $\mathrm{TR}^{\mathrm{st}}$ and a lower $\mathrm{TR}^{\mathrm{cu}}$ than plants treated with low SWC. High EC combined with low SWC showed the additive effect of low SWC and high EC by decreasing $\mathrm{TR}^{\text {st }}$ and $\mathrm{TR}^{\text {cu }}$ (Table 3 ). The results of stomata] and cuticular transpiration in situ were consistent with those obtained from the transpiration curve analyses mentioned above. Decreases in $\mathrm{TR}^{\mathrm{st}}$ and $\mathrm{TR}^{\mathrm{cu}}$ are plant adaptations to environmental stresses (Svenningson and Ljenberg, 1986). Our results support this hypothesis. A previous study showed that treatments with high EC and low SWC increased water use efficiency by decreasing transpiration, especially in high EC treated plants under low PPF (Xu et al., 1994). The results described herein are consistent with the results from the previous study.

Wax content. Wax content was higher in high EC and/or low soil water treated plants than the control plants in middle (the 10th from the uppermost) and upper leaves (the 5th) (Table 4). Wax content was lower in young leaves than in old leaves. An additive effect was also apparent between high EC and low soil water. Wax content measurements were inversely proportional to those of $\mathrm{TR}^{\mathrm{cu}}$ mentioned above. Plants treated with high EC and/or low SWC having high wax content on their leaf surface show low $\mathrm{TR}^{\mathrm{cu}}$. It is suggested that more wax deposition prevents water loss from the cuticle. As other researchers suggested (Baker, 1982; Jordan et al., 1983), decreases in $\mathrm{TR}^{\mathrm{cu}}$ water loss due to increased wax deposition on and/or in the leaf surface, together with the sensitive and adjustable stomatal resistance, constitute the water vapor diffusion barrier across the leaf-air boundary layer. This is one type of mechanism used by plants to avoid leaf dehydration stress. Another adaptation mechanism is the enforced water stress tolerance by turgor maintenance and osmotic adjustment. The increase in maximum transpiration rate in previously high EC and/or low substrate water treated plants after dehydration supports the hypothesis that osmotic adjustment and turgor regulation occurred in high EC and/or low substrate water treated plants (Xu et al., 1994).

\section{Conclusion}

The objective of this study was to examine the effects of high $\mathrm{EC}$ and low soil water on $\mathrm{TR}^{\mathrm{st}}$ and $\mathrm{TR}^{\mathrm{CU}}$. The data clearly indicated that $\mathrm{TR}^{\mathrm{st}}$ and $\mathrm{TR}^{\mathrm{cu}}$ were decreased by low soil water and high EC treatments. However, when the plants previously treated with high EC and/or low SWC were fully dehydrated with water, the initial maximum transpiration rate measured by the gas-exchange method was higher than in control plants. The measured time during which stomata remained open or partially open was longer in low soil water and high EC treated plants as determined by the water retention curve method with excised leaves and the transpiration decline curve method in the gas-exchange system. This suggests that stomata of high EC and/or water-stressed plants remained open for longer periods than those of well-watered plants when the water supply was stopped. Relative water content at which stomata closed was lower in high EC and/or water-stressed plants than for low EC treated and nonstressed plants. This suggests that the high $\mathrm{EC}$ and/or water-stressed plants could maintain $\mathrm{CO}_{2}$ assimilation and transpiration by maintaining relatively high stomatal conductance under low water status. The RWC after 160 min of transpiration was higher in high $\mathrm{EC}$ and/or water-stressed plants than in nonstressed plants. This suggests that the leaves of high EC and/ or water-stressed plants showed high water retention ability when the water supply was stopped. Higher water retention ability was attributed to lower $\mathrm{TR}^{\mathrm{st}}$ and $\mathrm{TR}^{\mathrm{cu}}$. The treatment of high EC combined with low SWC showed the additive effect of the individual stresses on most of the variables measured. Increased wax content was correlated with reduced $\mathrm{TR}^{\mathrm{CU}}$. This suggests that increases in wax deposit prevents water loss from the cuticle. 


\section{Literature Cited}

Baker, E.A. 1974. The influence of environment on leaf wax development in Brassica oleracea var. gemmifera. New Phytol. 73:955-966.

Baker, E.A. 1982. Chemistry and morphology of plant epicuticular waxes, p. 139-165. In: D.F. Cutler, K.L. Alvin and C.E. Price (eds.). The plant cuticle. Academic Press, London.

Bengtson, C., S. Larsson, and C. Lijienberg. 1978. Effect of water stress on cuticular transpiration rate and amount and composition of epicuticular wax in seedlings of six oat varieties. Physiol. Plant. 44:319-324.

Chaves, M.M. 1991. Effects of water deficits on carbon assimilation. J. Expt. Bot. 42:1-16.

Chaves, M.M. and M.L. Rodrigues. 1987. Photosynthesis and water relations in grapevines-Reponses to environmental factors, p. 379390. In: J. D. Tenhunen, F.M. Catarino, O.L. Lange, and W.C. Oechel (eds.). Plant response to stress, functional analysis in Mediterranean ecosystems. Springer-Verlag, Berlin.

Ebercon, A., A. Blum, and W.R. Jordan. 1977. A rapid colorimetric method for epicuticular wax content of sorghum leaves. Crop Sci. 17:179-180.

Jordan, W. R., R.L. Monk, F.R. Miller, D.T. Rosenow, L.E. Clark, and P.J. Shouse. 1983. Environmental physiology of sorghum. I. Environmental and genetic control of epicuticular wax load. Crop Sci. 23:352-358.

Haas, K. 1977. Einfluß von temperatur und Blattalter auf das cuticular wachs von Hedera helix. Biochem. Physiol. Pflanz. $171: 25-31$.
Osmond, C. B., M.P. Austin, J.A. Berry, W.D. Billings, and W.E. Winner. 1987. Stress physiology and distribution of plants. Bioscience 37:3848.

Quisenberry, J. E., B. Roark, and B.L. McMichael. 1982. Use of transpiration decline curves to identify drought-tolerant cotton germplasm. Crop Sci. 22:9 18-922.

Richards, R. A., H.M. Rawson, and D.A. Johnson. 1986. Glaucousness in wheat: Its development and effect on water-use efficiency, gas exchange and photosynthetic tissue temperatures. Austral. J. Plant Physiol. 13:465473.

Schönherr, J. 1982. Resistance of plant surfaces to water transport properties of cutin, suberin and associated lipids, p. 153-179. In: O.L. Lang, P.S. Nobel, C.B. Osmond, and H. Ziegler (eds.). Physiological plant ecology. Encyclopedia of plant physiology. vol. 12B. SpringerVerlag, Berlin.

Svenningsson, M. and C. Lijenberg. 1986. Changes in cuticular transpiration rate and cuticular lipids of oat (Avena sativa) seedlings induced by water stress. Physiol. Plant. 66:9-14.

Whitecross, M.I. and D.J. Armstrong. 1972. Environmental effects on epicuticular waxes of Brassica napus. Austral. J. Bet. 20:87-95.

Xu, H.L., L. Gauthier, and A. Gosselin. 1994. Photosynthetic response of greenhouse tomato plants to high solution electrical conductivity and low soil water content. J. Hort Sci. 69:821-832.

Yue, D., Y. Desjardins, M. Lammare, and A. Gosselin. 1992. Photosynthesis and transpiration of in vitro cultured asparagus plantlets. Scientia Hort. 49:9-16. 